\title{
Ethnopharmacological Survey on Treatment of Hypertension by Traditional Healers in Bukavu City, DR Congo
}

\author{
Félicien Mushagalusa Kasali $\mathbb{D}^{1,2}$ Christian Ahadi Irenge ${ }^{10},{ }^{1}$ \\ Pacifique Murhula Hamuli $\mathbb{D}^{1},{ }^{1}$ Patient Birindwa Mulashe, ${ }^{1}$ \\ Delphin Murhula Katabana $\mathbb{D}^{3},{ }^{3}$ Jean De Dieu Mangambu Mokoso $\mathbb{D}^{4}$, \\ Pius Tshimankinda Mpiana $\mathbb{D}^{5},{ }^{5}$ and Justin Ntokamunda Kadima $\mathbb{D}^{1,6}$
}

\author{
${ }^{1}$ Department of Pharmacy, Faculty of Pharmaceutical Sciences and Public Health, Official University of Bukavu, Bukavu, \\ Democratic Republic of the Congo \\ ${ }^{2}$ Pharm-Biotechnology and Traditional Medicine Center of Excellence, Department of Pharmacy, \\ Mbarara University of Science and Technology, Mbarara, Uganda \\ ${ }^{3}$ Department of Internal Medicine, Faculty of Medicine, Official University of Bukavu, Bukavu, Democratic Republic of the Congo \\ ${ }^{4}$ Department of Biology, Faculty of Science and Applied Sciences, Official University of Bukavu, Bukavu, \\ Democratic Republic of the Congo \\ ${ }^{5}$ Department of Chemistry, Faculty of Science, University of Kinshasa, Kinshasa, Democratic Republic of the Congo \\ ${ }^{6}$ School of Medicine, College of Medicine and Health Sciences, University of Rwanda, Kigali, Rwanda
}

Correspondence should be addressed to Félicien Mushagalusa Kasali; felicienkasali@gmail.com

Received 4 November 2020; Revised 7 June 2021; Accepted 3 July 2021; Published 12 July 2021

Academic Editor: Keturah R. Faurot

Copyright (c) 2021 Félicien Mushagalusa Kasali et al. This is an open access article distributed under the Creative Commons Attribution License, which permits unrestricted use, distribution, and reproduction in any medium, provided the original work is properly cited.

\begin{abstract}
Background. Ethnopharmacological studies are relevant for sustaining and improving knowledge of traditional medicine within the framework of complementary/alternative therapeutic practices based solely on experience and observation across generations. Hypertension is a common cardiovascular disorder affecting more than 50\% of older people in Africa (PLoS One. 2019; 14 (4): e0214934; published online on April 5, 2019, doi: 10.1371/journal.pone.0214934). Methods. We conducted a cross-sectional survey from October 2014 to August 2015 with 18 renowned traditional healers from the city of Bukavu to capture botanical plant species and remedies used by herbalists to manage hypertension in the Democratic Republic of Congo. Results. Respondents cited 41 plant species belonging to 25 botanical families. The ten most common plants are Allium sativum, Galinsoga ciliata, Moringa oleifera, Bidens pilosa, Persea americana, Piper capense, Catharanthus roseus, Rauvolfia vomitoria, Sida rhombifolia, and Vernonia amygdalina. The parts used are primary leaves (48.8\%) formulated as oral decoctions (65.9\%). Conclusion. The literature review validated the use of $73.2 \%$ of the plants listed. Plants of high local use-value not supported by other studies deserve in-depth chemical and pharmacological studies.
\end{abstract}

\section{Introduction}

Hypertension (HT) is a permanent rise in blood pressure with systole $>140 \mathrm{mmHg}$ and diastole $>90 \mathrm{mmHg}$, resulting from arterial disturbance of the vascular tree $[1,2]$. Numerous molecular signaling entities are part of the pathogenesis of HT, presuming a homeostatic imbalance $[1,2]$. Several pathological events can increase the relationship between the thickness of the vascular wall and the dimensions of the arterial lumen. These can be increased arterial responsiveness (sensitivity and potency) due to deregulation of endothelial nitric oxide synthase (eNOS) and prooxidant enzymes, increased basal and activated calcium levels due to transmembrane permeability of calcium (VSMC), hyperplasia, and hypertrophy (vascular remodeling). HT represents the most growing component of the burden of 
cardiovascular disease (CVD). Globally, around $40 \%$ of adults aged 25 and over suffer from HT, which represents more than a billion people [3], mainly among the black population in urban and rural communities in sub-Saharan Africa [4-6].

For centuries, herbal remedies have played a central role in managing HT and other cardiovascular diseases. The discovery of highly active synthetic drugs has somewhat clouded herbal medicine, especially in wealthy Western countries. In poor rural communities in Africa, herbal remedies remain an essential part of traditional medicine, which is part of complementary/alternative medicine (CAM) [7-9]. The popularity of CAMs in African populations relates to more straightforward accessibility at a lower cost than Western therapies [10]. Patients receive social treatment from friends, relatives, and traditional healers with previous good experiences. The positive results are due to the placebo or the actual efficacy [10]. It is also interesting to note that there is currently a revival of CAM in developed countries.

The rationale for using herbal remedies comes as no surprise, given that they contain thousands of bioactive components that have known therapeutic applications [11]. A diverse range of plant and herbal extracts and their metabolites can modulate signaling cascades implicated in cardiovascular physiology. Various plants have provided a starting point for synthesizing more than $50 \%$ of the pharmaceutical drugs currently in use [12]. Cases of ephedrine (Ephedra sinica), aspirin (Salix alba), lovastatin (Monascus purpureus), and reserpine (Rauvolfia serpentine) are illustrative [12]. Reserpine depletes adrenergic neurotransmitters and remains an effective treatment for HT [13] in association with other medicines.

This study aimed to explore how local healers in Bukavu city in the eastern Democratic Republic of Congo (DRC) manage HT with plants. A recent survey in Bukavu [14] showed that $9.7 \%(189 / 1948)$ of hospitalized patients, $57 \%$ men and $43 \%$ women aged $23-88$ years, presented with a hypertensive crisis. The majority had severe HT with BP $>180 / 110$, including $24.4 \%$ urgency and $76 \%$ emergency. Target organ damage was stroke (32\%), heart failure (24.6\%), chronic kidney disease (19.7\%), and whether or not associated with diabetes (39.8\%); comorbidities were respiratory distress, urinary tract infections, sepsis, malaria, gastritis, and cancer. Some patients recognized having combined traditional and modern medication. Ethnopharmacological surveys are considered essential for the acquisition and protection of ancestral medical heritage. In addition, evidence-based scientific studies are worth taking to validate the efficacy claimed by traditional healers and to determine bioactive chemicals.

\section{Methods}

2.1. Study Design and Area. The study was a cross-sectional survey conducted in the city of Bukavu with 18 renowned traditional healers from October 2014 to August 2015 to capture botanical plant species, remedy formulations, and dosage. We searched the literature for similarities with other countries and evidence-based pharmacological surveys. The city of Bukavu, capital of South Kivu Province, is located in the eastern part of the Democratic Republic of the Congo (Figure 1), between $2^{\circ} 3^{\prime}$ of latitude $S$ and $28^{\circ} 50^{\prime}$ of longitude $\mathrm{E}$ at $1600 \mathrm{~m}$ of average altitude illustrating a mountainous relief. The climate is tropical humid with a short dry season (3-4 months), and the temperature is moist at the edge of Lake Kivu [15]. Although the city is cosmopolitan, most of the population speaks Swahili, and the dominant ethnolinguistic groups are the Bashi and Lega.

2.2. Respondents and Investigation. The respondents' selection started with identifying the traditional practitioners recognized by the Traditional Healers Association operating in the town. We finally selected 18 practitioners working in Bagira, Ibanda, and Kadutu health districts who agreed to deliver their knowledge about using plants treating HT. The information collected focused on the respondent's identity and qualification, the plants' botanical specifications, the preparation of the remedies, and the administration mode. A literature review served to verify whether the plants quoted have similar indications elsewhere and what would be their mechanisms of action.

2.3. Statistical Evaluation of the Importance of Species. Three indexes often express the frequency of quoting for botanical families and plant species [16]: the Relative Frequency of Citation $(R F C=F C / N ; 0<R F C<1)$ index, where $\mathrm{FC}$ is the number of informants who mentioned the use of the species and $\mathrm{N}$ is the total number of informants; Fidelity Level $[F L(\%)=N P / N \times 100]$ indicating the percentage of informants claiming the use of a specific plant species for the same primary purpose, where $\mathrm{Np}$ is the number of informants that claimed use of a plant species to treat a particular disease and $\mathrm{N}$ is the number of informants that used plants as a medicine to treat any given disease; and Use Value ( $\mathrm{UV}=\Sigma U / n)$, where $U$ is the number of usable reports for a given plant species cited by each informant and $n$ is the total number of informants interviewed for a given plant.

\section{Results}

3.1. Demographics of Informants. As shown in Table 1, 18 informants participated in the study. They lived in 3 different counties, namely, Bagira $(n=7)$, Kadutu $(n=7)$, and Ibanda $(n=4)$. They qualified themselves as healers $(n=4)$, spiritualists $(n=1)$, and herbalists $(n=13)$. The majority were men $(n=14)$, and a few were women $(n=4)$, aged between 35 and 70 years, practicing for more than ten years.

3.2. Ethnopharmacological Information. Table 2 summarizes ethnopharmacological crude data and the calculated importance of each plant. The informants named the plants in their different dialects or scientific names. Qualified botanists of the university helped matching vernacular and scientific names. The analysis of data found 41 plant species cited 165 times belonging to 23 plant families. The fidelity level (FL \%) and relative frequency of citation (RFC) and 


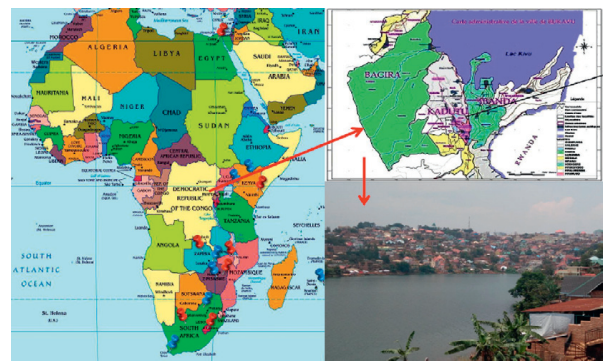

Figure 1: Map of Bukavu city in the Democratic Republic of Congo.

TABLE 1: Characteristics of informants.

\begin{tabular}{lccr}
\hline Demographic & District & $N$ & $\%$ \\
\hline \multirow{3}{*}{ Address } & Bagira & 7 & 38.9 \\
& Kadutu & 7 & 38.9 \\
\hline \multirow{3}{*}{ Qualification } & Ibanda & 4 & 22.2 \\
& Healer & 4 & 22.2 \\
\hline \multirow{2}{*}{ Gender } & Spiritualist & 1 & 5.6 \\
& Herbalist & 13 & 72.2 \\
\hline \multirow{2}{*}{ Age } & Male & 14 & 77.8 \\
& Female & 4 & 22.2 \\
\hline \multirow{2}{*}{ Work experience } & $35-45$ years & 6 & 33.3 \\
& $46-65$ years & 9 & 50.0 \\
& $66-70$ years & 3 & 16.7 \\
\hline
\end{tabular}

use-value (UV) as defined above varied between 2.5 and $32.5 \%$ and $0.056-0.722$ and $0.0061-0.0788$. A decoction is prepared by boiling 1 to 5 handful(s) of the fresh part or powder in 1 to 2 liters of water for $30 \mathrm{~min}$ to 2 hours. Infusions are obtained by soaking the leaves or other parts of the plant in 1-2 liters of boiled water and then filtering the liquid. Based on the types of formulations prepared, the only route of administration is oral. The standard measurement unit is frequently a glass $(\mathrm{Gb}=150 \mathrm{ml})$ generally taken two or three times per day for 5-15 days.

3.3. Quantitative Analysis of Data. Figure 2 presents the frequencies of the 23 botanical families. Asteraceae and Fabaceae are the two dominant with six species, each $(14.63 \%)$. Figures 3 and 4 show the frequency of plant parts used and formulations. The main plant parts used were leaves $20(48.8 \%)$, aerial parts $5(12.2 \%)$, barks $4(9.8 \%)$, and roots $4(9.8 \%)$, formulated as decoction (65.9\%), infusion (17.1\%), maceration $(7.3 \%)$ in water, drug powder $(4.9 \%)$, or crude material $(4.9 \%)$.

\section{Literature Discussion}

4.1. Ethnopharmacological Knowledge. We did not assess the understanding of the interviewees about the physiopathology of hypertension. To our knowledge, based on multiple workshops organized with the association of traditional healers, the hallmark of hypertension is headache, dizziness, and eye redness.
For the pharmaceutical state of the art, leaves and aerial parts are the most used parts in formulating remedies. The frequent use of leaves is associated with ease of accessibility among plants' aboveground parts in natural ecosystems [17]. Decoction has often been found as the principal formulation of herbal remedies as it is easy to prepare by mixing a drug with boiling water [18]. The dosing interval and duration of use show that the treatment is more likely for crisis and not for chronic control. Some patients use both conventional and complementary therapies, with an unknown risk of interaction harming.

4.2. Ethnobotanical Knowledge. Also, the comprehensive ecological status of individual plants was beyond our objectives. For more details, refer to the references mentioned. The majority of plants listed are of Asteraceae and Fabaceae families. The literature indicates that, out of 250,000 species of flowering plants known, nearly one in ten is a member of the Asteraceae, a diverse family found in almost every habitat in all continents except Antarctica [19]. Bukavu is no exception.

In the consulted literature, the ten top-cited plants were Allium sativum, Persea americana, Moringa oleifera, Catharanthus roseus, Bidens pilosa, Ageratum conyzoides, Rauvolfia vomitoria, Conyza sumatrensis, Passiflora edulis, Piper capense, and Sida rhombifolia.

4.3. The Similarity of Local and Literature Data. Almost all plant species recorded, but 11(26.8\%), have validated similar traditional uses in the literature. Table 3 presents the most 
TABLe 2: Antihypertensive medicinal plants used by 18 traditional healers in Bukavu.

\begin{tabular}{|c|c|c|c|c|c|c|c|c|c|}
\hline Scientific name & Botanical family & Local names & $\begin{array}{c}\mathrm{FL} \\
\%\end{array}$ & RFC & UV & $\begin{array}{l}\text { Parts } \\
\text { used }\end{array}$ & \multicolumn{2}{|c|}{ Form preparation } & Dose $\mathrm{Rx} /$ days \\
\hline $\begin{array}{l}\text { Acanthus arboreus } \\
\text { Forssk. }\end{array}$ & Acanthaceae & Ludarhu (Ma) & 2.5 & 0.056 & 0.0061 & $\mathrm{Lv}$ & $\mathrm{D}$ & $2 \mathrm{hf} / \mathrm{L}$ & $3 \times 1 \mathrm{gb} / 7$ \\
\hline $\begin{array}{l}\text { Ageratum conyzoides (L.) } \\
\text { L. }\end{array}$ & Asteraceae & Munianzigi (Ma) & 20.0 & 0.444 & 0.0485 & AP & $\mathrm{D}$ & $4 \mathrm{hf} / 2 \mathrm{~L}$ & $3 \times \mathrm{ts} / 10$ \\
\hline Allium cepa $\mathrm{L}$. & Amaryllidaceae & Itunguru $(\mathrm{Ma})$ & 7.5 & 0.167 & 0.0181 & $\mathrm{Bb}$ & $\begin{array}{l}\text { Slice } \\
\mathrm{D}\end{array}$ & $\begin{array}{l}\text { Juice } 1 \mathrm{hf} / \\
2 \mathrm{~L}\end{array}$ & $\begin{array}{l}\text { Chew as } \\
\text { needed }\end{array}$ \\
\hline Allium sativum $\mathrm{L}$. & Amaryllidaceae & Itunguru sumu $(\mathrm{Ma})$ & 32.5 & 0.722 & 0.0788 & $\mathrm{Bb}$ & $\mathrm{D}$ & $1 \mathrm{hf} / 2 \mathrm{~L}$ & $2 \times 0.5 \mathrm{gb} / 7$ \\
\hline $\begin{array}{l}\text { Anacardium occidentale } \\
\text { L. }\end{array}$ & Anacardiaceae & Pome $(\mathrm{Sw})$ & 2.5 & 0.056 & 0.0061 & $\mathrm{Bk}$ & M & $10 \mathrm{~g} / 2 \mathrm{~L}$ & $2 \times 1 \mathrm{gb} / 7$ \\
\hline $\begin{array}{l}\text { Ananas comosus (L.) } \\
\text { Merr. }\end{array}$ & Bromeliaceae & Inanasi $(\mathrm{Ma})$ & 2.5 & 0.056 & 0.0061 & $\mathrm{Fr}$ & $\mathrm{D}$ & Slide/L & $2 \times 1 \mathrm{gb} / 7$ \\
\hline Arachis hypogaea $\mathrm{L}$. & Fabaceae & $\begin{array}{l}\text { Akabemba }(\mathrm{Ma}) \text { and } \\
\text { Kalanga }(\mathrm{Sw})\end{array}$ & 5.0 & 0.111 & 0.0121 & $\mathrm{Lv}$ & $\mathrm{D}$ & $3 \mathrm{hf} / \mathrm{L}$ & $2 \times 1 \mathrm{gb} / 7$ \\
\hline $\begin{array}{l}\text { Astrochlaena grantii } \\
\text { Rendle }\end{array}$ & Convolvulaceae & Nfubia (Ma) & 2.5 & 0.056 & 0.0061 & Ro & Pw & $\mathrm{Mix}+\mathrm{Pw}$ & Lick the $\mathrm{Pw}$ \\
\hline Bambusa vulgaris Schrad. & Poaceae & Mulonge (Ma) & 10.0 & 0.222 & 0.0242 & $\mathrm{Lv}$ & $\mathrm{D}$ & $4 \mathrm{hf} / 2 \mathrm{~L}$ & $1 \mathrm{gb} /$ \\
\hline Basella alba $\mathrm{L}$. & Arecaceae & $\begin{array}{l}\text { Nderema (Ma) and } \\
\text { Ndelema (Le) }\end{array}$ & 5.0 & 0.111 & 0.0121 & $\mathrm{Lv}$ & I & $2 \mathrm{hf} / \mathrm{L}$ & $2 \times 0.5 \mathrm{gb} / 7$ \\
\hline Bidens pilosa L. & Asteraceae & Kashisha (Ma) & 20.0 & 0.444 & 0.0485 & AP & $\mathrm{D}$ & $3 \mathrm{hf} / \mathrm{L}$ & $3 \times 0.5 / 7$ \\
\hline Brassica oleracea L. & Brassicaceae & Shu $(\mathrm{Sw})$ & 2.5 & 0.056 & 0.0061 & $\mathrm{Lv}$ & $\mathrm{I}$ & $2 \mathrm{hf} / \mathrm{L}$ & As needed \\
\hline Capsicum annuum L. & Solanaceae & Lipipiri (Ma) & 5.0 & 0.111 & 0.0121 & $\mathrm{Lv}$ & $\mathrm{D}$ & $1 \mathrm{~kg} / 2 \mathrm{~L}$ & $2 \times 1 \mathrm{gb} /$ \\
\hline Cassia alata $\mathrm{L}$. & Fabaceae & & 7.5 & 0.167 & 0.0181 & $\mathrm{Bk}$ & I & $2 \mathrm{hf} / \mathrm{L}$ & $2 \times 0.5 \mathrm{gb} / 7$ \\
\hline $\begin{array}{l}\text { Cassia didymobotrya } \\
\text { Fresen. }\end{array}$ & Fabaceae & Mukakabazimu (Ma) & 7.5 & 0.167 & 0.0181 & $\mathrm{Lv}$ & $\mathrm{D}$ & $3 \mathrm{hf} / \mathrm{L}$ & $2 \times 0.5 \mathrm{gb} / 7$ \\
\hline $\begin{array}{l}\text { Catharanthus roseus (L.) } \\
\text { G.Don }\end{array}$ & Apocynaceae & Vinca $(S w)$ & 15.0 & 0.333 & 0.0364 & $\mathrm{Lv}$ & $\mathrm{D}$ & $1 \mathrm{hf} / \mathrm{L}$ & $3 \times 1 \mathrm{gb} / 7$ \\
\hline $\begin{array}{l}\text { Chenopodium opulifolium } \\
\text { Schrad. ex W.D.J.Koch \& } \\
\text { Ziz }\end{array}$ & Amaranthaceae & Mwigembagembye (Ma) & 2.5 & 0.056 & 0.0061 & $\mathrm{Lv}$ & I & $2 \mathrm{hf} / \mathrm{L}$ & $2 \times 1 \mathrm{gb} / 7$ \\
\hline $\begin{array}{l}\text { Citrus aurantiifolia } \\
\text { (Christm.) Swingle }\end{array}$ & Rutaceae & & 10.0 & 0.222 & 0.0242 & $\mathrm{Lv}$ & I & $100 \mathrm{~g} / 2 \mathrm{~L}$ & $2 \times 1 \mathrm{gb}$ \\
\hline $\begin{array}{l}\text { Conyza sumatrensis } \\
\text { (S.F.Blake) Pruski \& } \\
\text { G.Sancho }\end{array}$ & Asteraceae & Mulashahugwe (Ma) & 12.5 & 0.278 & 0.0303 & $\mathrm{AP}$ & $\mathrm{D}$ & $3 \mathrm{hf} / \mathrm{L}$ & $3 \times 0.5 / 7$ \\
\hline Dissotis trothae Gilg & Melastomataceae & $\begin{array}{c}\text { Ciberabana and Ikebya } \\
(\mathrm{Ma})\end{array}$ & 12.5 & 0.278 & 0.0303 & $\mathrm{Bk}$ & M & $\mathrm{Pw} / \mathrm{L}$ & $2 \times 1 \mathrm{gb} / 14$ \\
\hline $\begin{array}{l}\text { Drymaria cordata (L.) } \\
\text { Willd. ex Schult. }\end{array}$ & Caryophyllaceae & Bwahulo (Ma) & 10.0 & 0.222 & 0.0242 & $\mathrm{Lv}$ & I & $1 \mathrm{ts} / \mathrm{L}$ & $1 \mathrm{~L}$ \\
\hline $\begin{array}{l}\text { Dyschoriste perrottetii } \\
\text { (Nees) Kuntze }\end{array}$ & Acanthaceae & Cumumia (Ma) & 12.5 & 0.278 & 0.0303 & Ro & I & $2 \mathrm{hf} / \mathrm{L}$ & $3 \times 1 \mathrm{gb} / 7$ \\
\hline Elaeis guineensis Jacq. & Arecaceae & Ngazi (Sw) & 2.5 & 0.056 & 0.0061 & $\mathrm{Lv}$ & $\mathrm{D}$ & $3 \mathrm{hf} / 2 \mathrm{~L}$ & $1 \mathrm{gb} / 7$ \\
\hline $\begin{array}{l}\text { Erlangea ugandensis } \\
\text { S.Moore }\end{array}$ & Asteraceae & Lwibaye (Ma) & 7.5 & 0.167 & 0.0181 & Ro & Pw & Mix Pw & Lick the $\mathrm{Pw}$ \\
\hline $\begin{array}{l}\text { Galinsoga ciliata (Raf.) } \\
\text { S.F.Blake }\end{array}$ & Asteraceae & Iragala $(\mathrm{Ma})$ & 25.0 & 0.556 & 0.0606 & $\mathrm{AP}$ & $\mathrm{D}$ & $3 \mathrm{hf} / \mathrm{L}$ & $2 \times 1 \mathrm{gb} / 7$ \\
\hline $\begin{array}{l}\text { Hypoestes triflora } \\
\text { (Forssk.) Roem. \& Schult. }\end{array}$ & Acanthaceae & Mboza (Ma) & 12.5 & 0.278 & 0.0303 & $\mathrm{Lv}$ & $\mathrm{D}$ & $2 \mathrm{hf} / \mathrm{L}$ & $2 \times 0.5 \mathrm{gb} / 7$ \\
\hline Indigofera arrecta A.Rich. & Fabaceae & Kasholoza (Ma) & 7.5 & 0.167 & 0.0181 & Ro & $\mathrm{D}$ & $\mathrm{Pw} / \mathrm{L}$ & $2 \times 0.5 \mathrm{gb} / 7$ \\
\hline Kotschya africana Endl. & Fabaceae & Lwazi (Ma) & 7.5 & 0.167 & 0.0181 & $\mathrm{Sm}$ & $\mathrm{D}$ & $3 \mathrm{hf} / 3 \mathrm{~L}$ & $2 \times 1 \mathrm{gb} / 7$ \\
\hline Moringa oleifera Lam. & Moringaceae & $\begin{array}{l}\text { Mti maria (Ma) and } \\
\text { Mlongelonge (Sw) }\end{array}$ & 25.0 & 0.556 & 0.0606 & $\mathrm{Lv}$ & $\mathrm{D}$ & $3 \mathrm{hf} / 2 \mathrm{~L}$ & As needed \\
\hline Passiflora edulis Sims & Passifloraceae & Irakucha $(\mathrm{Ma})$ & 12.5 & 0.278 & 0.0303 & $\mathrm{Lv}$ & $\mathrm{D}$ & $5 \mathrm{hf} / \mathrm{L}$ & $3 \times 1 \mathrm{gb} /$ \\
\hline Persea americana Mill. & Lauraceae & Mvokati (Ma) & 20.0 & 0.444 & 0.0484 & $\mathrm{Lv}$ & $\mathrm{D}$ & $5 \mathrm{hf} / 2 \mathrm{~L}$ & $3 \times 1 \mathrm{gb} / 7$ \\
\hline Phaseolus lunatus L. & Fabaceae & Kambenga (Ma) & 2.5 & 0.056 & 0.0061 & $\mathrm{Sm}$ & $\mathrm{D}$ & $3 \mathrm{hf} / 3 \mathrm{~L}$ & As needed \\
\hline Piper capense L.f. & Piperaceae & Nkoza (Ma) & 17.5 & 0.389 & 0.0424 & $\mathrm{Fr}$ & I & $\begin{array}{l}29 \mathrm{gPw} / \\
2 \mathrm{~L}\end{array}$ & $2 \times 1 \mathrm{gb} / 15$ \\
\hline Rauvolfia vomitoria Afzel. & Apocynaceae & Katando (Ma) & 15.0 & 0.333 & 0.0364 & Ro & $\mathrm{D}$ & $\mathrm{Pw} / \mathrm{L}$ & As needed \\
\hline Sida rhombifolia L. & Melastomataceae & Mudundu (Ma) & 15.0 & 0.333 & 0.0364 & $\mathrm{Lv}$ & $\mathrm{Cr}$ & Juice & Chew \\
\hline Solanum lycopersicum L. & Solanaceae & Itomati (Ma) & 5.0 & 0.111 & 0.0121 & $\mathrm{Lv}$ & M & $200 \mathrm{~g} / 2 \mathrm{~L}$ & $2 \times 1 \mathrm{gb} / 2$ \\
\hline
\end{tabular}


TABLE 2: Continued.

\begin{tabular}{|c|c|c|c|c|c|c|c|c|c|}
\hline Scientific name & Botanical family & Local names & $\begin{array}{c}\text { FL } \\
\%\end{array}$ & RFC & UV & $\begin{array}{l}\text { Parts } \\
\text { used }\end{array}$ & \multicolumn{2}{|c|}{ Form preparation } & Dose $\mathrm{Rx} /$ days \\
\hline Terminalia catappa L. & Combretaceae & & 2.5 & 0.056 & 0.0061 & Ro & $\mathrm{Pw}$ & Mix Pw & Lick the Pw \\
\hline $\begin{array}{l}\text { Vernonia amygdalina } \\
\text { Delile }\end{array}$ & Asteraceae & Mubirizi (Ma) & 10.0 & 0.222 & 0.0242 & $\mathrm{AP}$ & $\mathrm{D}$ & $5 \mathrm{hf} / \mathrm{L}$ & $3 \times 1 \mathrm{gb} / 7$ \\
\hline Viscum album L. & Santalaceae & & 2.5 & 0.056 & 0.0061 & $\mathrm{Lv}$ & $\mathrm{D}$ & $5 \mathrm{hf} / 2 \mathrm{~L}$ & $2 \times 1 \mathrm{gb}$ \\
\hline Zea mays L. & Poaceae & Muhindi (Sw) & 10.0 & 0.222 & 0.0242 & Fw & $\mathrm{D}$ & $1 \mathrm{hf} / 2 \mathrm{~L}$ & $2 \times 1 \mathrm{ts} /$ \\
\hline Zingiber officinale Roscoe & Zingiberaceae & Tangawizi (Sw) & 7.5 & 0.167 & 0.0182 & $\mathrm{Rz}$ & $\mathrm{D}$ & $\begin{array}{c}2 \mathrm{hfPw} / \\
2 \mathrm{~L}\end{array}$ & As needed \\
\hline
\end{tabular}

Lv, leaves; Rz, rhizome; Fr, fruit; Bk, bark; Ro, root; Fw, flower; Bb, bulb; Sm, stem; AP, aerial part; D, decoction; I, infusion; M, maceration; Pw, powder; Cr, crude; Pc, crushed piece; gb, glass of beer; hf, handful; ts, teaspoon; Ma, Mashi; Le, Lega; Sw, Swahili.

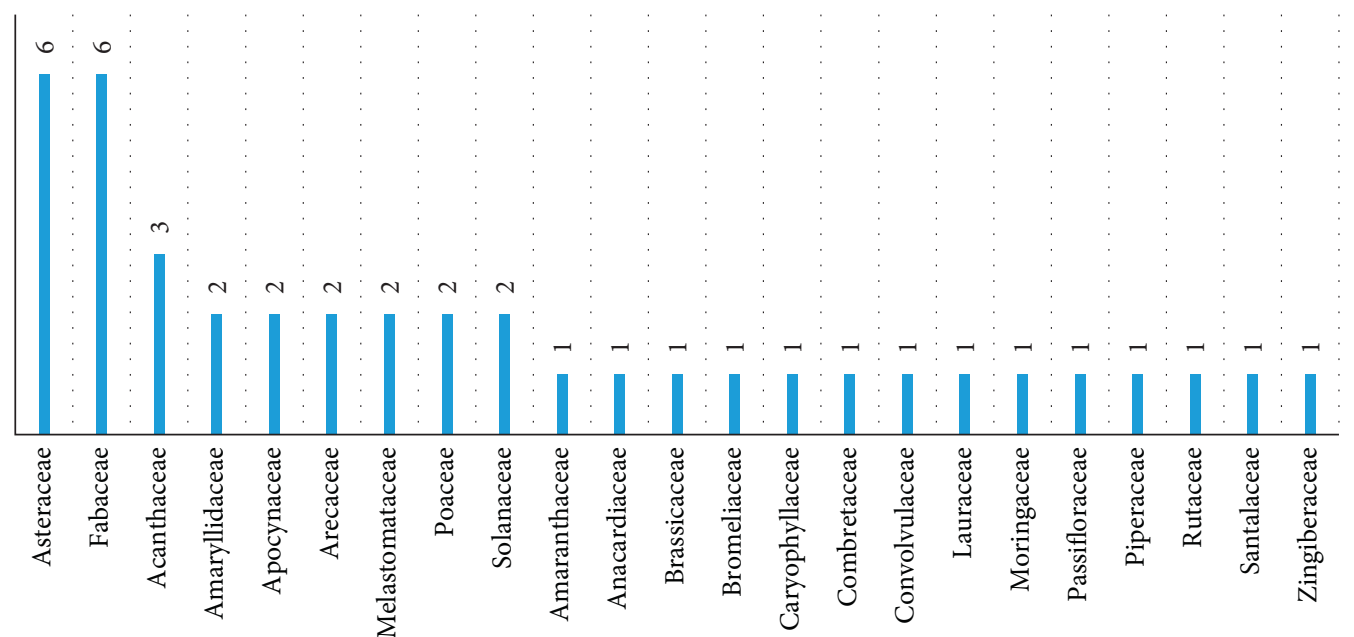

FIGURE 2: Frequencies of botanical families of antihypertensive plants from Bukavu city.

frequently cited species. For example, Galinsoga ciliata, Dissotis trothae, Dyschoriste perrottetii, and Hypoestes triflora were among the highly quoted locally $(\mathrm{RFC}=0.556-0.278)$ but not mentioned as antihypertensive plants in the literature consulted.

Galinsoga parviflora Cav, also called gallant soldier, is a cosmopolitan annual herb from the Asteraceae family native to South America and a near cosmopolitan weed of distributed places [33]. Fresh leaves and juice of G. parviflora have been used in folk medicine worldwide to treat dermatological disorders, including eczema, lichen, and nonhealed bleeding wounds. The use of G. parviflora as food by humans for making salad and soups in Latin and North America proves that the plant is nontoxic [34]. Dissotis trothae extracts have antidiarrhoeal action [35], and the leaves are used across Africa without strong scientific basis or safety concerns. Dyschoriste perrottetii Nees is an important medicinal plant used in various ways to treat microbial infections, fever, measles, and pains [36]. Hypoestes triflora aqueous leaf extract showed haematic and hepatoprotective potentials in guinea pigs [37]. Rauvolfia serpentine is widely used to manage HT, tachycardia, and thyrotoxicosis since 1952, but respondents did not list it in DRC flora. The ethnomedicine use of R.vomitoria is reported only in African countries (Nigeria and Cameroon). For the validated species, there is no more room for debate. Numerous original and review studies discussed multiple uses of Allium sativum, Anacardium occidentalis, Lycopersicum esculentum (Solanum lycopersicum), Persea americana, Ageratum conyzoides, and Zingiber officinale as antihypertensive herbs [17, 20-23, 26, 28, 30-32, 38, 39]. Moringa oleifera is well known worldwide [17, 22-24, 26-32, 39-42].

Besides HT treatment, traditional healers use the same plants to manage several diseases $[43,44]$. For example, they use Allium sativum for abdominal pain, intestinal parasites, infection, and stimulating immunity; Moringa oleifera for diabetes, cancer, vomiting, colic, headaches, tooth decay, delirium, inflammation, female infertility, fractures, hemorrhoids, and constipation; Persea America for anemia, constipation, kidney, fever, various pains, diarrhea, and sickle cell disease; and Vernonia amygdalina for malaria and intestinal worms, to name a few. Also, many plants are often used in association with two to four species. For example, Erlangea ugandensis is mixed with piper capense and palm salt.

4.4. Evidence-Based Pharmacological Studies. A diverse range of plant and herbal extracts and their metabolites can modulate signaling cascades implicated in the cardiovascular system's physiology (Figure 5). Different authors have explored the pharmacology and toxicology of Allium sativum [45-50]. Garlic inhibits ACE activity, and in this 


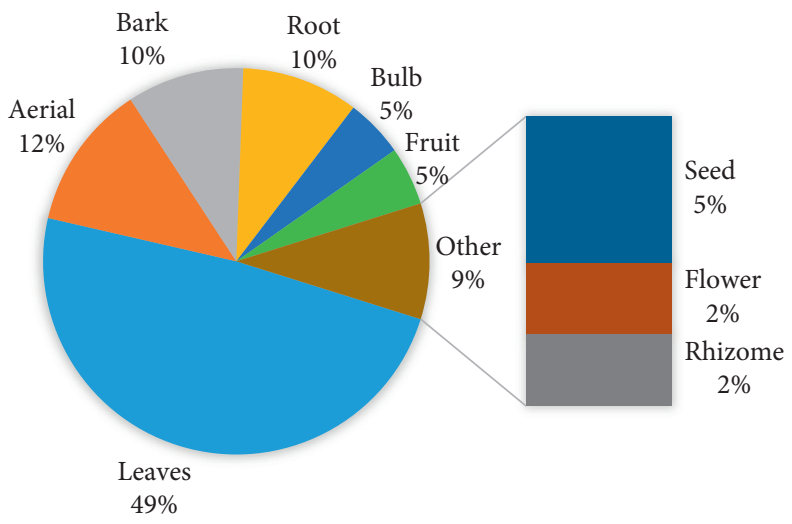

Figure 3: The frequency of plant parts used.

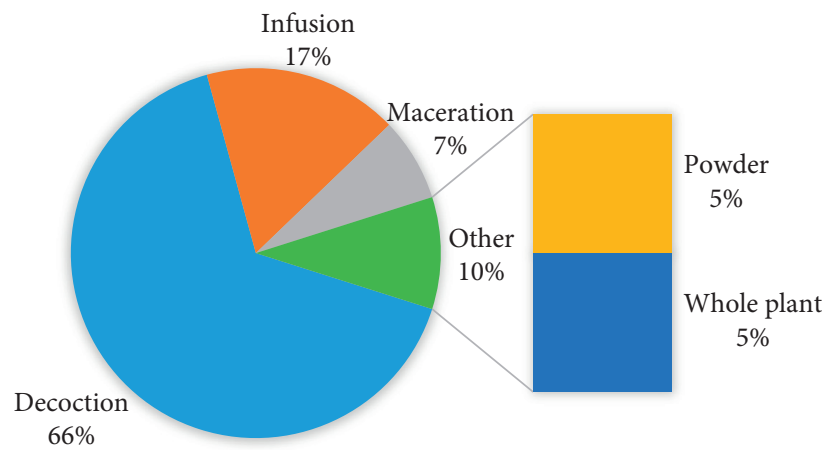

Figure 4: The frequency of remedy preparations.

TABLE 3: Frequencies of citation and validation in the literature.

\begin{tabular}{|c|c|c|c|c|c|}
\hline \multirow[t]{2}{*}{ Plant species } & \multicolumn{2}{|l|}{ Local RFC } & \multicolumn{2}{|c|}{ Literature ${ }^{*}$ RFC } & \multirow{2}{*}{$\begin{array}{c}\text { Literature } \\
\text { References }\end{array}$} \\
\hline & Number of respondents & RFC value & Number of papers & RFC value & \\
\hline Galinsoga ciliata & 10 & 0.556 & 0 & 0 & Not validated \\
\hline Dissotis trothae & 5 & 0.278 & 0 & 0 & Not validated \\
\hline Dyschoriste perrottetii & 5 & 0.278 & 0 & 0 & Not validated \\
\hline Hypoestes triflora & 5 & 0.278 & 0 & 0 & Not validated \\
\hline Allium sativum & 13 & 0.722 & 6 & 0.316 & {$[20-25]$} \\
\hline Persea americana & 8 & 0.444 & 5 & 0.263 & {$[20,21,24,26,27]$} \\
\hline Moringa oleifera & 10 & 0.556 & 4 & 0.211 & {$[22,27-29]$} \\
\hline Catharanthus roseus & 6 & 0.333 & 4 & 0.211 & {$[17,21,24,26]$} \\
\hline Bidens pilosa & 8 & 0.444 & 2 & 0.106 & {$[22,29]$} \\
\hline Ageratum conyzoides & 8 & 0.444 & 2 & 0.106 & {$[18,21]$} \\
\hline Rauvolfia vomitoria & 6 & 0.333 & 2 & 0.106 & {$[26,27]$} \\
\hline Conyza sumatrensis & 5 & 0.278 & 2 & 0.106 & {$[23,30]$} \\
\hline Passiflora edulis & 5 & 0.278 & 2 & 0.106 & {$[23,31]$} \\
\hline Piper capense & 7 & 0.389 & 1 & 0.052 & [26] \\
\hline Sida rhombifolia & 6 & 0.333 & 1 & 0.052 & {$[32]$} \\
\hline Total sources & 18 & & 19 & & \\
\hline
\end{tabular}

Relative frequency of citation (RFC).

regard, gamma-glutamyl-cysteines are the antagonists. The constituents of garlic antagonize vasoconstriction induced by endothelin-1 inhibit the proliferation of VSMCs in smooth muscles and abolish the activation of NF- $\kappa \mathrm{B}$. Numerous studies mention the antihypertensive potentials of
Allium cepa in animal models through different mechanisms such as increased expression of endothelial nitric oxide synthetase, regulation of extracellular $\mathrm{Ca}^{2+}$ levels, attenuation of induced contractions by phenylephrine and $\mathrm{KCl}$, and relaxation of the aorta. 


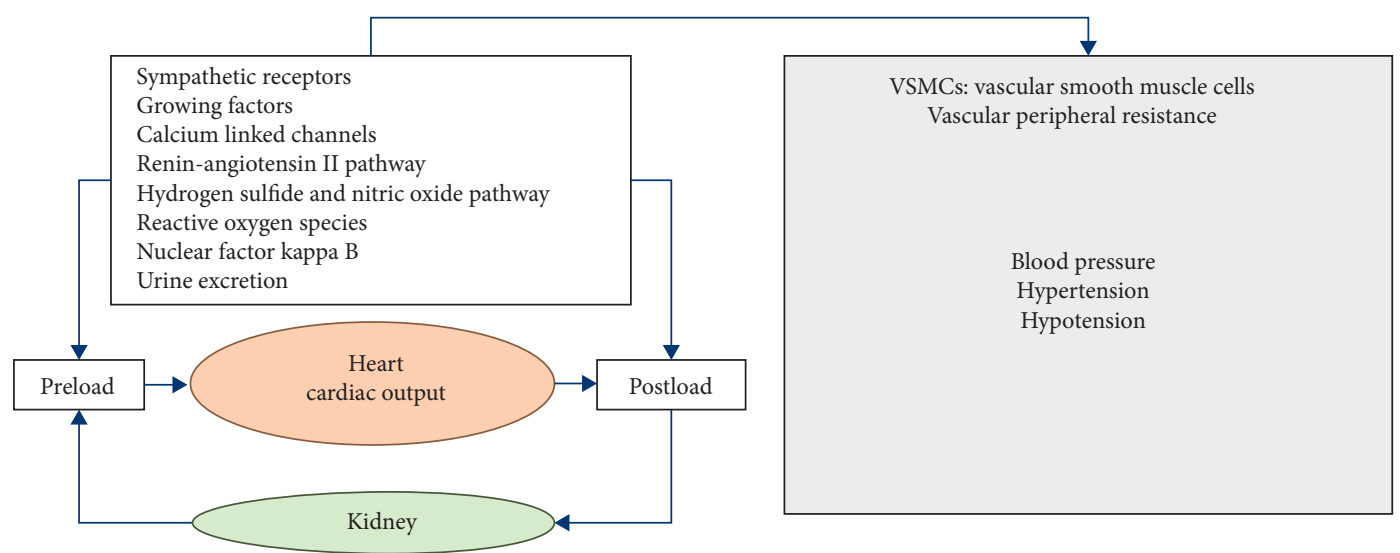

FIGURE 5: Some modulating mechanisms of blood pressure.

Bidens pilosa (Beggar's Tick, Black-Jack, etc.) possesses anticancer, antibacterial, antimalarial, and antiobesity properties alongside the antihypertensive effect [51-54]. Leaf extracts prevented and attenuated HBP in different hypertensive rat models. Cumulative doses of a neutral extract of B. pilosa (at an optimum concentration of $0.32 \mathrm{mg} / \mathrm{ml}$ ) relaxed $\mathrm{KCl}$ and noradrenaline preconstricted rat aortas. The mechanism of vasodilation is independent of ATP-sensitive potassium channels; it can involve calcium channel antagonism and cyclooxygenase inhibition.

Phaseolus lunatus contains protein hydrolysates with ACE-I Inhibitory Activity [55]. The aqueous extract of ginger $(0.05 \mathrm{mg} / \mathrm{ml})$ also inhibited lipid peroxidation and ACE in rat hearts [56]. Besides, zingerone, another active compound in Zingiber officinale, can potently scavenge oxidant molecules such as peroxynitrite. In a clinical study, administration of two bioactive constituents of ginger, namely, (6)-gingerol and (6)-shogoal orally (70-140 mg/kg) and intravenously $(1.75-3.5 \mathrm{mg} / \mathrm{kg})$, produced triphasic blood pressure profiles: initial rapid fall, intermediate rise, and finally, a delayed decrease in blood pressure [57]. Indeed, (6)-gingerol is now considered a novel angiotensin II type 1 receptor antagonist with an IC50 of $8.17 \times 10-6 \mathrm{M}$ [58].

The polyphenol-rich leaf extract of E. guineensis has shown vasodilator properties on the aorta and the mesenteric arterial bed such as norepinephrine, mainly via endothelium-dependent mechanisms $[59,60]$. It significantly increased serum NO, reduced lipid peroxidation, and showed antioxidant effects in hypertensive rats deficient in NO [59].

Moringa oleifera is an analgesic and has anti-inflammatory, antipyretic, anticancer, antioxidant, hepatoprotective, gastroprotective, and antiulcer properties [57, 61-63]. Active constituents for hypotensive action are niazinin $A$, niazinin $B$, and niazimicin [63]. The mechanism underlying this cardioprotective activity is the antioxidant effect, the prevention of lipid peroxidation, and the protection of histopathological disturbance [62].

4.5. Evidence-Based Toxicological Studies. Overall, toxicological investigations exist mainly in acute and subacute studies in animals, especially rodents. For example, local application of fresh garlic may cause burns (when on the skin, particularly under occlusive dressings). Studies on Allium [45, 64] suggested that S-alk(en)yl-1-cysteines have little potential to cause drug-drug interactions through human CYP inhibition or activation. However, garlic may enhance the anticoagulant effect of warfarin and reduce the efficacy of saquinavir in HIV/AIDs patients [64]. Also, the consumption of garlic by nursing mothers may modify their infant's behavior during breastfeeding; it seems contraindicated in pregnant women. Some case reports [64] highlighted garlic allergic reactions such as contact dermatitis, generalized urticaria, angioedema, pemphigus, anaphylaxis, alteration of platelet function, and coagulation with a possible risk of bleeding.

Alkaloids such as 1,2-dehydropyrrolizidine and N-oxides derivatives from Ageratum conyzoides could induce hepatotoxicity in humans [65]. Piperine, an amide alkaloid from the genus Piper, can depress the central nervous system [66]. Catharanthus roseus can be hallucinogenic when taken orally. The known side effects caused by R. serpentine include cardiotoxicity, gastrointestinal disorders, sedation, psychiatric depression, hypotension, nausea, bradycardia, and psychological. Reserpine, a bioactive indole alkaloid, is mainly responsible for these effects [67].

\section{Conclusions}

Traditional healers in Bukavu use many plants validated in the literature in antihypertensive phytotherapy. The plants with high local use-value not backed by other studies deserve in-depth chemical and pharmacological studies to elucidate bioactive compounds and their mechanisms of action.

\section{Limitations and Perspectives}

The list of plants and ethnopharmacological information given here may not be exhaustive due to the small number of informants interviewed. Also, it would be better desirable to contact rural healers who live far from the city. A future specific anthropological survey may help understand the perception of the healers and patients about hypertension, how they feel, symptoms, traditional diagnosis, and what 
happens when they consume a particular plant. The ultimate end-point of those studies is to come up with improved traditional medicines. Ethically, the authorship claimed by the informants should be regulated organizationally and culturally regarding the international Convention on Biological Diversity.

\section{Data Availability}

The data used in this study are provided and included within the article.

\section{Conflicts of Interest}

The authors declare no conflicts of interest.

\section{References}

[1] S. L. H. Ong and J. A. Whitworth, "How do glucocorticoids cause hypertension: role of nitric oxide deficiency, oxidative stress, and eicosanoids," Endocrinology and Metabolism Clinics of North America, vol. 40, no. 2, pp. 393-407, 2011.

[2] A. C. Montezano and R. M. Touyz, "Molecular mechanisms of hypertension-reactive oxygen species and antioxidants: a basic science update for the clinician," Canadian Journal of Cardiology, vol. 28, no. 3, pp. 288-295, 2012.

[3] Z.-Q. Yang, Q. Zhao, P. Jiang, S.-B. Zheng, and B. Xu, "Prevalence and control of hypertension among a community of Elderly population in changning district of Shanghai: a cross-sectional study," BMC Geriatrics, vol. 17, no. 1, p. 296, 2017.

[4] P. Mangena, S. Saban, K. E. Hlabyago, and B. Rayner, "An approach to the young hypertensive patient," South African Medical Journal=Suid-Afrikaanse Tydskrif Vir Geneeskunde, vol. 106, no. 1, pp. 36-38, 2016.

[5] S. Tsabang N, E. Fongnzossie, D. Donfack et al., "Comparative study of epidemiological and anthropological aspects of diabetes and hypertension in Cameroon," Forest Research is the Best Open Access, vol. 5, no. 1, pp. 1-5, 2016.

[6] M. E. Hendriks, F. W. N. M. Wit, M. T. L. Roos et al., "Hypertension in sub-Saharan Africa: cross-sectional surveys in four rural and urban communities," PLoS One, vol. 7, no. 3, Article ID e32638, 2012.

[7] J. W. Stanifer, U. D. Patel, F. Karia et al., "The determinants of traditional medicine use in northern Tanzania: a mixedmethods study," PLoS One, vol. 10, no. 4, Article ID e0122638, 2015.

[8] B. Saad, H. Azaizeh, and O. Said, "Tradition and perspectives of arab herbal medicine: a review," Evidence-Based Complementary and Alternative Medicine, vol. 2, no. 4, pp. 475-479, 2005.

[9] A. Youbi, I. Ouahidi, L. Mansouri, A. Daoudi, and D. Bousta, "Ethnopharmacological survey of plants used for immunological diseases in four regions of Morocco," European Journal of Medicinal Plants, vol. 13, no. 1, pp. 1-24, 2016.

[10] F. Nuwaha and G. Musinguzi, "Use of alternative medicine for hypertension in Buikwe and Mukono districts of Uganda: a cross sectional study," BMC Complementary and Alternative Medicine, vol. 13, no. 1, p. 301, 2013.

[11] S. Y. Pan, S. F. Zhou, S. H. Gao et al., "New perspectives on how to discover drugs from herbal medicines: CAM'S outstanding contribution to modern therapeutics," Evidence-
Based Complementary and Alternative Medicine, vol. 2013, Article ID 627375, 25 pages, 2013.

[12] W. H. Frishman, P. Beravol, and C. Carosella, "Alternative and complementary medicine for preventing and treating cardiovascular disease," Disease-a-Month, vol. 55, no. 3, pp. 121-192, 2009.

[13] M. A. Weber, E. L. Schiffrin, W. B. White et al., "Clinical practice guidelines for the management of hypertension in the community," The Journal of Clinical Hypertension, vol. 16, no. 1, pp. 14-26, 2014.

[14] J. N. Kadima, B. Bavhure, J. D. Sepa, and D. Murhura, "Hypertensive urgencies or emergencies and co-morbidities in Bukavu Referral Hospitals: clinical profile, management regimens, outcomes and drug related problems," Journal of Basic and Clinical Pharmacy, vol. 9, no. 1, pp. 46-52, 2018.

[15] M. Mangambu, K. Mushagalusa, and N. Kadima, "Contribution à l'étude photochimique de quelques plantes médicinales antidiabétiques de la ville de Bukavu et ses environs (Sud-Kivu, R.D.Congo)," Journal of Applied Biosciences, vol. 75, no. 1, pp. 6211-6220, 2014.

[16] A. Bano, M. Ahmad, T. Ben Hadda et al., "Quantitative ethnomedicinal study of plants used in the Skardu valley at high altitude of Quantitative ethnomedicinal study of plants used in the Skardu valley at high altitude of KarakoramHimalayan range, Pakistan," Journal of Ethnobiology and Ethnomedicine, vol. 10, no. 43, 2014.

[17] M. F. Mahomoodally, A. Mootoosamy, and S. Wambugu, "Traditional therapies used to manage diabetes and related complications in Mauritius: a comparative ethnoreligious study," Evidence-Based Complementary and Alternative Medicine, vol. 2016, Article ID 4523828, 25 pages, 2016.

[18] L. Ahmad, A. Semotiuk, M. Zafar et al., "Ethnopharmacological documentation of medicinal plants used for hypertension among the local communities of DIR lower, Pakistan," Journal of Ethnopharmacology, vol. 175, pp. 138146, 2015.

[19] M. J. Moshi, D. F. Otieno, A. Weisheit et al., "Ethnomedicine of the Kagera Region, north western Tanzania. Part 3: plants used in traditional medicine in Kikuku village, Muleba District," Journal of Ethnobiology and Ethnomedicine, vol. 8, no. 1, p. 14, 2012.

[20] G. Mesa, "Antihypertensive potential of plants used in Cuba," Pharmacologyonline, vol. 2, pp. 10-17, 2014.

[21] F. T. Bi, G. Irie, K. N'Gaman, and C. Mahou, “Études de quelques plantes thérapeutiques utilisées dans le traitement de l'hypertension artérielle et du diabète: deux maladies émergentes en Côte d'Ivoire," The Science of Nature, vol. 5, no. 1, pp. 39-48, 2008.

[22] A. A. Diafouka and J. Lejoly, "Plantes hypotensives utilisées en médecine traditionnelle à Brazzaville (Congo)," in Proceedings of the Actes du 2émé Collogue Européen d'Ethnopharmacologie et de la 11émé Conférence Internationale d'Ethnomédecine, pp. 275-279, Heidelberg, Germany, March 1993.

[23] W. Kipkore, B. Wanjohi, H. Rono, and G. Kigen, "A study of the medicinal plants used by the Marakwet Community in Kenya," Journal of Ethnobiology and Ethnomedicine, vol. 10, no. 1, p. 24, 2014.

[24] N. O. Raji, I. M. Adebisi, and S. O. Bello, "Ethnobotanical survey of antihypertensive agents in Sokoto, Northwest Nigeria," International Journal Of Innovative Research \& Development, vol. 2, no. 5, pp. 1820-1835, 2013.

[25] S. Indu, P. Bharat, H. K. Dhamija, and S. Ritu, "An ayurvedic arena for hypertension treatment," Asian Journal of Pharmaceutical Research, vol. 2, no. 2, pp. 54-58, 2012. 
[26] T. Nole, T. Djeufack, W. Lionel et al., "Diabetes and arterial hypertension resorts of treatments and plants used for their treatments in three phytogeographic areas of Cameroon," International Journal of Traditional and Complementary Medicine, vol. 1, no. 4, pp. 45-59, 2016.

[27] K. Eghianruwa, O. Oridupa, and A. Saba, "Medicinal plants used for management of hypertension in Nigeria," Annual Research \& Review in Biology, vol. 11, no. 3, pp. 1-10, 2016.

[28] R. R. Fiscal, A. Concepcion, and C. Chavez, "Ethnobotanical profiling of commonly utilized plants for hypertension and diabetes in the province of Laguna, Philippines," International Journal of Science and Research, vol. 5, no. 9, pp. 152-154, 2016.

[29] U. F. Ezuruike and J. M. Prieto, "The use of plants in the traditional management of diabetes in Nigeria: pharmacological and toxicological considerations," Journal of Ethnopharmacology, vol. 155, no. 2, pp. 857-924, 2014.

[30] K. Kpegba, E. Amouzou, A. Agbonon, and M. Gbeassor, "Effect of Conyza aegyptiaca on the frog semi isolated heart," Journal of Applied Pharmaceutical Science, vol. 1, no. 7, pp. 36-39, 2011.

[31] M. G. S. Nunes, A. Bernardino, and R. D. Martins, "Use of medicinal plants by people with hypertension," Revista da Rede de Enfermagem do Nordeste, vol. 16, no. 6, pp. 775-781, 2015.

[32] J. K. Abat, S. Kumar, and A. Mohanty, "Ethnomedicinal, phytochemical and ethnopharmacological aspects of four medicinal plants of Malvaceae used in Indian traditional medicines: a Review," Medicines (Basel, Switzerland), vol. 4, no. 75, 2017.

[33] S. Ali, S. Zameer, and M. Yaqoob, "Ethnobotanical, phytochemical and pharmacological properties of Galinsoga parviflora (Asteraceae): a review," Tropical Journal of Pharmaceutical Research, vol. 16, no. 12, pp. 3023-3033, 2017.

[34] E. Studzinska-Sroka, M. Dudek-Makuch, J. Chanaj-Kaczmarek et al., "Anti-inflammatory activity and phytochemical profile of Galinsoga parviflora Cav," Molecules, vol. 232133 pages, 2018.

[35] T. A. Abere, P. E. Okoto, and F. O. Agoreyo, "Antidiarrhoea and toxicological evaluation of the leaf extract of Dissotis rotundifolia Triana (Melastomataceae)," BMC Complementary and Alternative Medicine, vol. 10, no. 71, 2010.

[36] U. E. Odoh, C. O. Ezugwu, and M. Ezejiofor, "Pharmacognostic studies on the leaves of Dyschoriste perottetii Nees," Pharmacognosy Journal, vol. 3, no. 24, pp. 11-14, 2011.

[37] B. Bavhure, M. Borive, and J. Kadima, "Haematic and hepatoprotective potentials of Hypoestes triflora aqueous leaf extract in Guinea-pigs," International Journal of Pharmaceutical Sciences and Research, vol. 5, no. 9, pp. 3726-3732, 2014.

[38] I. Sharma, B. Parashar, H. K. Dhamija, and R. Sharma, "An Ayurvedic arena for hypertension treatment," An Ayurvedic Arena for Hypertension Treatment, vol. 2, no. 2, pp. 54-58, 2012.

[39] S. Rubattu, S. Di Castro, M. Cotugno et al., "Protective effects of Brassica oleracea sprouts extract toward renal damage in high-salt-fed SHRSP," Journal of Hypertension, vol. 33, no. 7, pp. 1465-1479, 2015.

[40] I. A. Taiwo, P. Godwin, C. Odeigah, S. I. Jaja, and F. B. Mojiminiyi, "Cardiovascular effects of vernonia amygdalina in rats and the implications for treatment of hypertension in diabete," Medicine, vol. 2, no. 1, pp. 76-79, 2010.

[41] Y. S. Ch'ng, Y. C. Loh, C. S. Tan et al., "Vasorelaxant properties of vernonia amygdalina ethanol extract and its possible mechanism," Pharmaceutical Biology, vol. 55, no. 1, pp. 2083-2094, 2017.

[42] J. A. Saliu, A. O. Ademiluyi, A. J. Akinyemi, and G. Oboh, "In vitroantidiabetes and antihypertension properties of phenolic extracts from bitter leaf (vernonia amygdalinadel.)," Journal of Food Biochemistry, vol. 36, no. 5, pp. 569-576, 2012.

[43] N. Kadima, A. Marhegeko, F. Kasali, and N. Mugaruka, "Medicinal plants used in alternative medicine to treat cancer in Bukavu," European Journal of Medicinal Plants, vol. 12, no. 3, pp. 1-13, 2016.

[44] M. F. Kasali, A. O. Mahano, F. M. Bwironde et al., "Ethnopharmacological survey of plants used against diabetes in Bukavu city (D.R. Congo)," Journal of Ethnobiology and Traditional Medicine, vol. 119, pp. 538-546, 2013.

[45] Y. Kodera, M. Ushijima, H. Amano, J. I. Suzuki, and T. Matsutomo, "Chemical and biological properties of s-1propenyl-1-cysteine in aged garlic extract," Molecules (Basel, Switzerland), vol. 22570 pages, 2017.

[46] V. K. Singh and D. K. Singh, "Pharmacological effects of garlic (Allium sativum L.)," Annual Review of Biomedical Data Science, vol. 10, pp. 6-26, 2008.

[47] R. Shouk, A. Abdou, K. Shetty, D. Sarkar, and A. H. Eid, "Mechanisms underlying the antihypertensive effects of garlic bioactives," Nutrition Research, vol. 34, no. 2, pp. 106-115, 2014.

[48] A. Send, G. Elba, B. Steinke et al., "Comparative pharmacological investigations of Allium ursinum and Allium sativum," Planta Medica, vol. 58, no. 1, pp. 1-7, 1992.

[49] C. Castro, A. G. Lorenzo, A. González, and M. Cruzado, "Garlic components inhibit angiotensin II-induced cell-cycle progression and migration: involvement of cell-cycle inhibitor p27Kip1 and mitogen-activated protein kinase," Molecular Nutrition \& Food Research, vol. 54, no. 6, pp. 781-787, 2010.

[50] W. Qidwai and T. Ashfaq, "Role of garlic usage in cardiovascular disease prevention: an evidence-based approach," Evidence-Based Complementary and Alternative Medicine, vol. 2013, Article ID 125649, 9 pages, 2013.

[51] T. Dimo, S. V. Rakotonirina, P. V. Tan, J. Azay, E. Dongo, and G. Cros, "Leaf methanol extract of Bidens pilosa prevents and attenuates the hypertension induced by high-fructose diet in Wistar rats," Journal of Ethnopharmacology, vol. 83, no. 3, pp. 183-191, 2002.

[52] A. P. Bartolome, I. M. Villaseñor, and W. C. Yang, "Bidens pilosa L. (Asteraceae): botanical properties, traditional uses, phytochemistry, and pharmacology," Evidence-Based Complementary and Alternative Medicine, vol. 2013, Article ID 340215, 51 pages, 2013.

[53] T. Dimo, J. Azay, P. V. Tan et al., "Effects of the aqueous and methylene chloride extracts of Bidens pilosa leaf on fructosehypertensive rats," Journal of Ethnopharmacology, vol. 76, no. 3, pp. 215-221, 2001.

[54] T. B. Nguelefack, T. Dimo, E. P. N. Mbuyo, P. V. Tan, S. V. Rakotonirina, and A. Kamanyi, "Relaxant effects of the neutral extract of the leaves ofBidens pilosa Linn on isolated rat vascular smooth muscle," Phytotherapy Research, vol. 19, no. 3, pp. 207-210, 2005.

[55] L. Chel-Guerrero, M. Domínguez-Magaña, A. MartínezAyala, G. Dávila-Ortiz, and D. Betancur-Ancona, "Lima bean (Phaseolus lunatus) protein hydrolysates with ACE-I inhibitory activity," Food Science \& Nutrition, vol. 3, no. 4, pp. 511-521, 2012.

[56] A. J. Akinyemi, A. O. Ademiluyi, and G. Oboh, "Aqueous extracts of two varieties of ginger (zingiber officinale) inhibit angiotensin I-converting enzyme, iron(II), and sodium 
nitroprusside-induced lipid peroxidation in the rat HeartIn vitro," Journal of Medicinal Food, vol. 16, no. 7, pp. 641-646, 2013.

[57] D. K. Dubey, J. Dora, A. Kumar, and R. K. Gulsan, “A Multipurpose tree-Moringa oleifera," International Journal of Pharmaceutical and Chemical Sciences, vol. 2, no. 1, pp. 415-423, 2013.

[58] Q. Liu, J. Liu, H. Guo et al., "[6]-Gingerol: a novel AT1 antagonist for the treatment of cardiovascular disease," Planta Medica, vol. 79, no. 5, pp. 322-326, 2013.

[59] J. M. Jaffri, S. Mohamed, N. Rohimi et al., "Antihypertensive and cardiovascular effects of catechin-rich oil palm (Elaeis guineensis) leaf extract in nitric oxide-deficient rats," Journal of Medicinal Food, vol. 14, no. 7/8, pp. 775-783, 2011.

[60] B. V. Owoyele and G. O. Owolabi, "Traditional oil palm (Elaeis guineensis Jacq.) and its medicinal uses: a review," Tang [Humanitas Medicine], vol. 4, no. 3, p. e16, 2014.

[61] T. Tshabalala, B. Ncube, N. E. Madala et al., "Scribbling the cat: a case of the "miracle" plant, Moringa Oleifera," Plants, vol. 8510 pages, 2019.

[62] J. Mehta, A. Shukla, V. Bukhariya, and R. Charde, "The magic remedy of Moringa oliferia: an overview," International Journal of Biomedical and Advance Research, vol. 2, no. 6, pp. 215-227, 2011.

[63] S. Y. Dangi, C. I. Jolly, and S. Narayanan, "Antihypertensive activity of the total alkaloids from the leaves of Moringa oleifera," Pharmaceutical Biology, vol. 40, no. 2, pp. 144-148, 2002.

[64] F. Borrelli, R. Capasso, and A. A. Izzo, "Garlic (Allium sativumL.): adverse effects and drug interactions in humans," Molecular Nutrition \& Food Research, vol. 51, no. 11, pp. 1386-1397, 2007.

[65] C. F. Bosi, D. W. Rosa, R. Grougnet et al., "Pyrrolizidine alkaloids in medicinal tea of Ageratum conyzoides," Revista Brasileira de Farmacognosia, vol. 23, no. 3, pp. 425-432, 2013.

[66] H. Takooree, M. Z. Aumeeruddy, K. R. R. Rengasamy et al., “A systematic review on black pepper (Piper nigrum L.): from folk uses to pharmacological applications," Critical Reviews in Food Science and Nutrition, vol. 59, pp. S210-S243, 2019.

[67] J. Ruszkowska, R. Chrobak, J. T. Wróbel, and Z. Czarnocki, "Novel bisindole derivatives of Catharanthus alkaloids with potential cytotoxic properties," Advances in Experimental Medicine and Biology, vol. 527, pp. 643-646, 2003. 